\title{
Gambaran histopatologik hati tikus Wistar yang diberi ekstrak daun kelor (Moringa oleifera) setelah diinduksi karbon tetraklorida $\left(\mathbf{C C l}_{4}\right)$
}

\author{
${ }^{1}$ Satriani Syahrin \\ ${ }^{2}$ Carla Kairupan \\ ${ }^{2}$ Lily Loho
}

\author{
${ }^{1}$ Kandidat Skripsi Fakultas Kedokteran Universitas Sam Ratulangi Manado \\ ${ }^{2}$ Bagian Patologi Anatomi Fakultas Kedokteran Universitas Sam Ratulangi Manado \\ Email: satriani.12319@yahoo.com
}

\begin{abstract}
Moringa (Moringa oleifera) is a traditional plant, which is known to treat liver disease. The effect of moringa is related to the antioxidant activity of its compounds such as quercetin and flavonoid silymarin which are useful as liver protector. Carbon tetraclorida is a hepatotoxic substance that is usually used as an inducer of liver damage in studies related to hepatoprotector activity of a substance. This study aimed to describe liver histopathological features of Wistar rats fed with moringa leaf extract after $\mathrm{CCl}_{4}$ induction. This was an experimental study using 24 Wistar rats (Rattus norvegicus) which were divided into 4 groups. Group A, the negative control, was terminated at day $6^{\text {th }}$, and the other groups $(\mathrm{B}, \mathrm{C}$, and $\mathrm{D})$ were induced with $\mathrm{CCl}_{4} 0.05 \mathrm{cc} /$ day for 5 days. After $\mathrm{CCl}_{4}$ induction, group $\mathrm{B}$ were terminated at day $6^{\text {th }}$; group $\mathrm{C}$ was treated with moringa leaf extract $100 \mathrm{mg} /$ day for 5 days and was terminated at day $11^{\text {th }}$; group D received no treatment for 5 days and was terminated at day $11^{\text {th }}$. The results showed that groups induced with $\mathrm{CCl}_{4}$ for 5 days showed the presence of inflammatory cells and fatty cells. The groups treated with moringa leaf extract $100 \mathrm{mg} /$ day for 5 days after $\mathrm{CCl}_{4}$ induction $0.05 \mathrm{cc} /$ day exhibited regeneration of liver cells in nearly all lobules. Conclusion: Administration of moringa leaf extract of $100 \mathrm{mg} /$ day could accelerate liver cell regeneration of Wistar rats after induction of $\mathrm{CCl}_{4} 0.05 \mathrm{cc} / \mathrm{day}$.
\end{abstract}

Keywords: moringa leaf extract, carbon tetrachloride, histopathologogical image of liver

\begin{abstract}
Abstrak: Kelor merupakan tanaman tradisional yang diketahui dapat mengobati penyakit hati. Khasiat obat tanaman kelor dihubungkan dengan kandungan senyawa kimia quercetin dan silymarin golongan flavonoid dengan aktivitas antioksidan yang dapat melindungi dan mengobati kerusakan hati. Karbon tetraklorida merupakan zat hepatotoksik yang lazim dipakai sebagai penginduksi kerusakan hati dalam pengujian aktivitas hepatoprotektor suatu zat. Penelitian ini bertujuan untuk mengetahui gambaran histopatologik hati tikus wistar yang diberi ekstrak daun kelor (Moringa oleifera) setelah diinduksi $\mathrm{CCl}_{4}$. Jenis penelitian ini ialah eksperimental menggunakan 24 ekor tikus Wistar spesies Rattus norvegicus yang dibagi dalam 4 kelompok. Kelompok A merupakan kelompok kontrol negatif, diterminasi pada hari ke-6; kelompok $\mathrm{B}, \mathrm{C}$, dan $\mathrm{D}$ (kelompok perlakuan) diberi $\mathrm{CCl}_{4}$ dengan dosis $0,05 \mathrm{cc} / \mathrm{hari}$ selama 5 hari. Setelah pemberian $\mathrm{CCl}_{4}$, kelompok B langsung diterminasi pada hari ke-6; kelompok C diberi ekstrak daun kelor $100 \mathrm{mg}$ /hari selama 5 hari, diterminasi pada hari ke-11; kelompok D tidak diberi perlakuan selama 5 hari, diterminasi pada hari ke-11. Hasil penelitian menunjukkan bahwa kelompok tikus yang diinduksi $\mathrm{CCl}_{4}$ selama 5 hari secara histopatologik memperlihatkan sel-sel radang dan perlemakan sel. Kelompok tikus yang diberi ekstrak daun kelor $100 \mathrm{mg} /$ hari selama 5 hari setelah diinduksi $\mathrm{CCl}_{4} 0,05 \mathrm{cc} /$ hari menunjukkan regenerasi sel hati, hampir di seluruh lobuli hati. Simpulan: Pemberian ekstrak daun kelor $100 \mathrm{mg} / \mathrm{hari}$ setelah induksi $\mathrm{CCl}_{4}$ 0,05 cc/hari dapat mempercepat regenerasi sel hati tikus Wistar yang mengalami cedera akibat $\mathrm{CCl}_{4}$.
\end{abstract}

Kata kunci: ekstrak daun kelor, karbon tetraklorida, gambaran histopatologik hati 
Kelor (Moringa oleifera) merupakan spesies yang paling terkenal dari tiga belas spesies genus Moringacae. Tanaman ini dapat tumbuh dengan cepat dan digambarkan sebagai salah satu tanaman yang paling bergizi di dunia. Daun kelor memiliki kandungan betakaroten melebihi wortel, mengandung protein melebihi kacang polong, mengandung vitamin $\mathrm{C}$ lebih banyak dibanding jeruk, kandungan kalsiumnya melebihi susu, mengandung zat besi lebih banyak dari bayam, dan kandungan kaliumnya lebih banyak dari pisang. ${ }^{1}$

Tanaman obat tradisional merupakan tumbuhan yang dipercaya memiliki khasiat dan telah digunakan sebagai bahan baku obat tradisional. Secara umum daun kelor berkhasiat sebagai antibakteri, anti-inflamasi, kebutuhan nutrisi, melancarkan ASI, gangguan penglihatan, dan perdarahan gusi. Daun kelor juga diketahui dapat mengobati penyakit hati karena memiliki senyawa kimia quercetin dan silymarin golongan flavonoid dengan aktivitas antioksidan yang berperan sebagai hepatoprotektor dan hepatoterapeutik. Daun kelor juga dikonsumsi masyarakat sebagai sayuran. ${ }^{2}$

Karbon tetraklorida merupakan zat hepatotoksik yang lazim dipakai sebagai penginduksi kerusakan hati sehingga sering digunakan dalam pengujian aktivitas hepatoprotektor suatu zat tertentu. Aktivitas metabolism $\mathrm{CCl}_{4}$ terutama oleh enzim sitokrom $\mathrm{P} 450$ di hati, dimana $\mathrm{CCl}_{4}$ diubah menjadi lebih reaktif dan toksik, dan menyebabkan kerusakan hati. ${ }^{3}$

Penelitian ini bertujuan untuk mengetahui gambaran histopatologik hati tikus wistar yang diberi ekstrak daun kelor (Moringa oleifera) setelah diinduksi $\mathrm{CCl}_{4}$.

\section{METODE PENELITIAN}

Jenis penelitian ini ialah eksperimental laboratorik yang dilakukan pada bulan September 2015 sampai Februari 2016 di Laboratoriun Patologi Anatomi Fakultas Kedokteran Universitas Sam Ratulangi Manado. Subyek penelitian ialah 24 ekor tikus Wistar dewasa yang dibagi dalam 4 kelompok: Kelompok A (kontrol negatif), tidak diberi perlakuan selama 5 hari dan diterminasi hari ke-6; kelompok B diinduksi $\mathrm{CCl}_{4}$ selama 5 hari dan diterminasi hari ke-6; kelompok $\mathrm{C}$ diinduksi $\mathrm{CCl}_{4}$ selama 5 hari dilanjutkan dengan pemberian ekstrak daun kelor selama 5 hari dan diterminasi hari ke-11; dan kelompok D diinduksi $\mathrm{CCl}_{4}$ selama 5 hari kemudian tidak diberi perlakuan selama 5 hari berikutnya dan diterminasi hari ke-11. Organ hati diproses untuk pembuatan preparat histopatologik dan dievaluasi gambaran mikroskopik jaringan hati.

Ekstrak daun kelor (Moringa oleifera) yang digunakan ialah ekstrak etanol yang dibuat di Laboratorium Fakultas Matematika dan Ilmu Pengetahuan Alam Universitas Sam Ratulangi Manado. Dosis ekstrak daun kelor yang dipakai yaitu $100 \mathrm{mg} /$ tikus/hari sedangkan dosis $\mathrm{CCl}_{4}$ ialah $0,05 \mathrm{ml} / \mathrm{hari}^{4}{ }^{4}$

\section{HASIL PENELITIAN}

Jaringan hati tikus kelompok A menunjukkan struktur dan sel-sel normal dengan vena sentralis dan segitiga Kiernan. (Gambar 1).

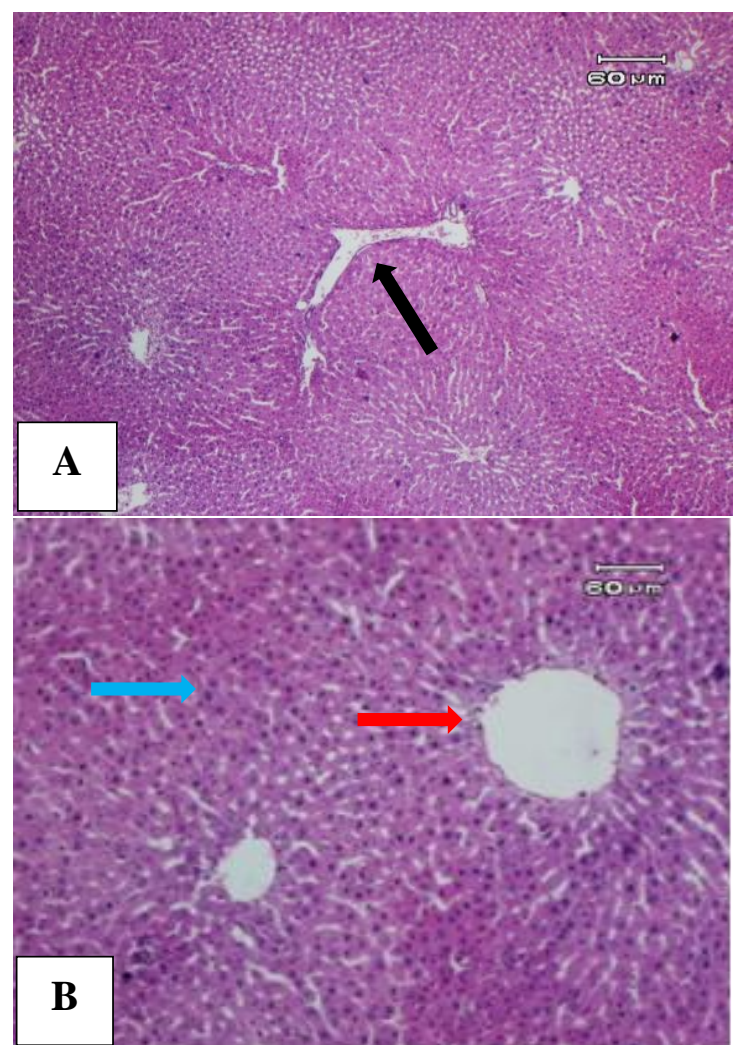

Gambar 1. Gambaran mikroskopik hati tikus Wistar kelompok kontrol negatif. Tampak gambaran hati normal dengan vena sentralis 
berada di tengah (panah merah), sel-sel hati (panah biru) dan segitiga Kiernan (panah hitam). A: pembesaran 10x10, B: pembesaran $10 \times 40$.

Pada kelompok B, gambaran histopatologik hati tikus menunjukkan adanya steatosis makro dan mikrovesikuler dimana pada sitoplasma sel-sel hati terdapat vakuola-vakuola kecil yang tidak mendesak inti dan vakuola besar yang mendesak inti sel ke tepi. Tampak juga adanya sel-sel radang PMN (Gambar 2).
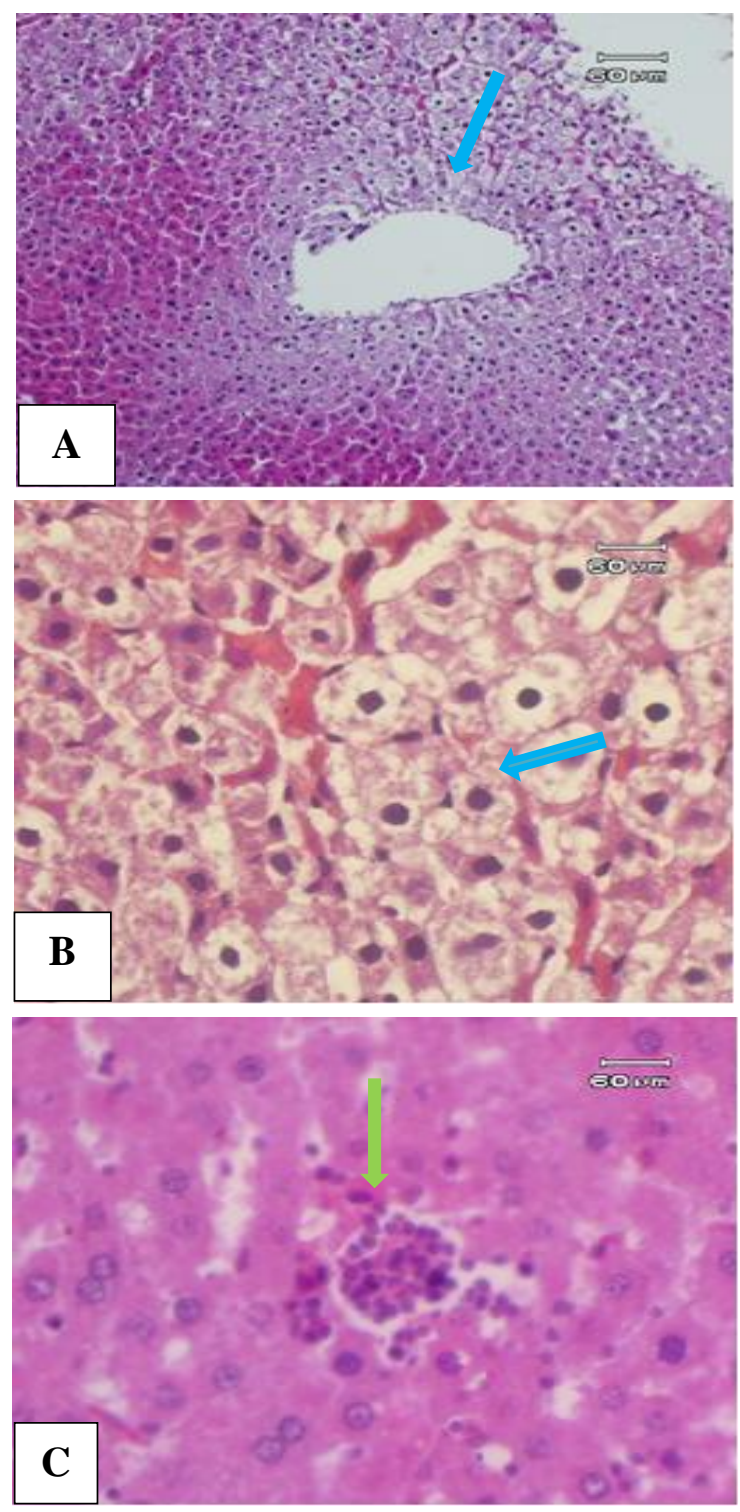

Gambar 2. Gambaran mikroskopik hati tikus Wistar kelompok B. Tampak gambaran hati dengan perlemakan (panah biru) dan sel radang (panah hijau). A: pembesaran 10x10, B dan C: pembesaran 10x40.
Pada kelompok C tampak sel-sel hati sudah mulai mengalami regenerasi pada hampir seluruh lobuli hati, ditandai dengan inti sel ganda dan inti sel besar dengan sitoplasma lebih eosinofil. Tampak pula sel-sel normal (Gambar 3).

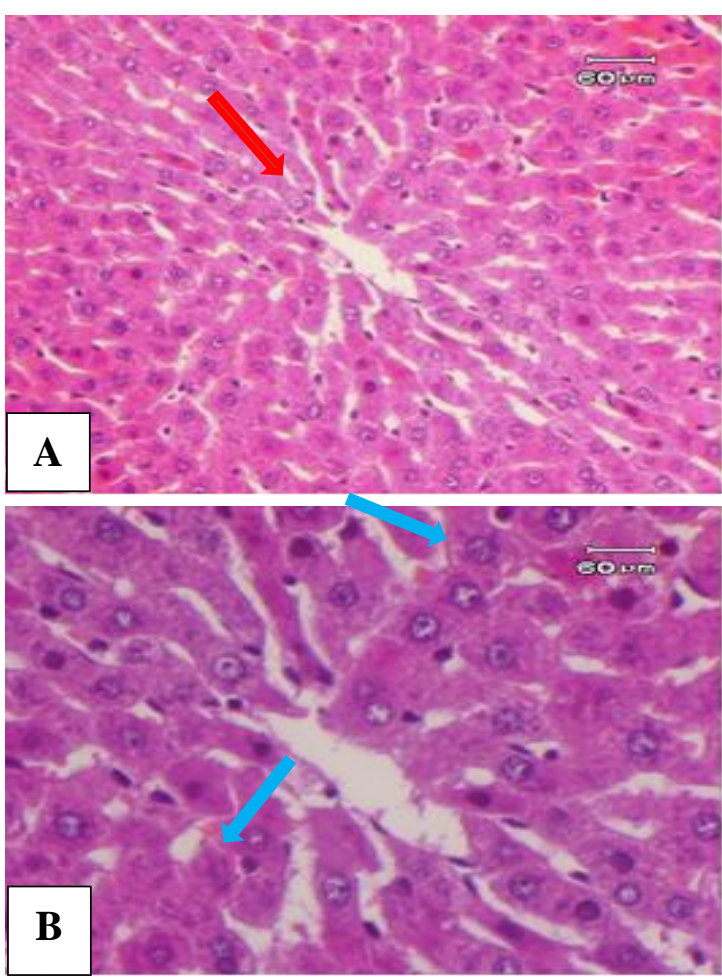

Gambar 3. Gambaran mikroskopik hati tikus Wistar kelompok C. Tampak gambaran regenerasi sel hati dengan inti sel ganda (panah biru) dan sel hati normal (panah merah). A: pembesaran 10x20, B: pembesaran 10x40.

Pada kelompok D terlihat sedikit sel regenerasi dan masih ada perlemakan serta pembengkakan sel hati (pembengkakan keruh) di sekitar vena sentralis (Gambar 4). Perbandingan jumlah sel yang mengalami peradangan, perlemakan, dan regenerasi sel.

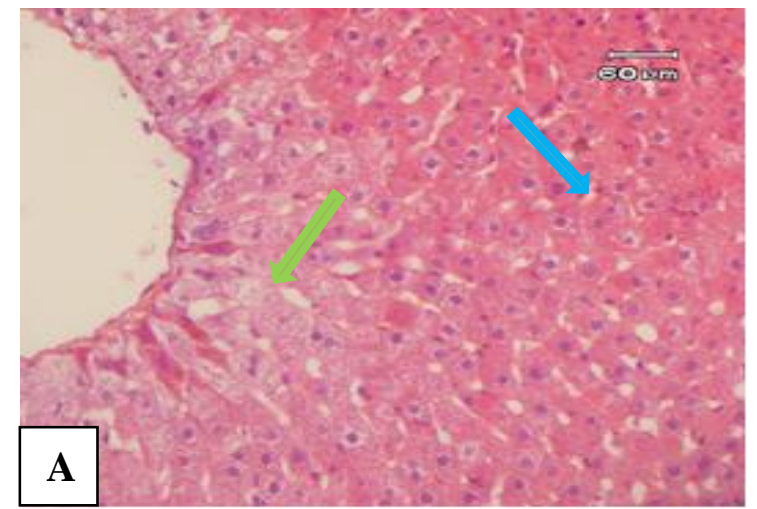




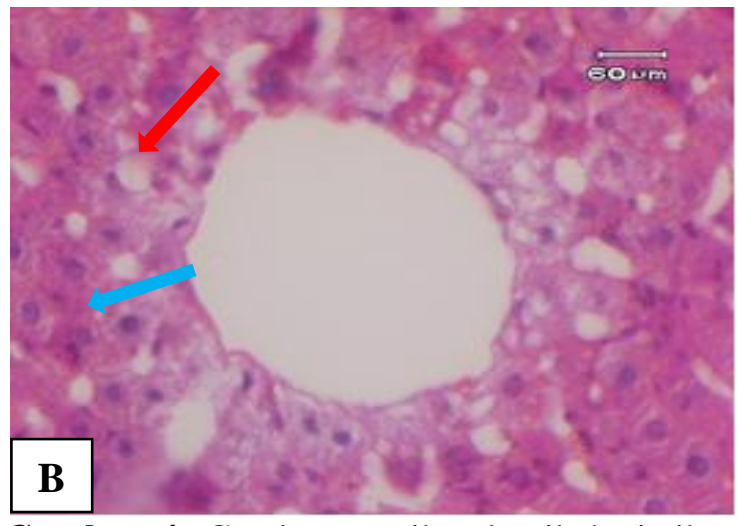

Gambar 4. Gambaran mikroskopik hati tikus wistar kelompok D. Tampak sedikit regenerasi sel hati (panah biru), masih ada perlemakan (panah merah) dan pembengkakan sel (panah hijau). A: pembesaran 10x20, B: pembesaran $10 \times 40$.

\section{BAHASAN}

Hasil penelitian ini memberikan data perbandingan mengenai gambaran histopatologik hati tikus wistar yang diberi dan tidak diberi ekstrak daun kelor setelah induksi $\mathrm{CCl}_{4}$. Gambaran mikroskopik jelas menunjukkan perbedaan antara hati tikus kelompok kontrol negatif (kelompok A) dan kelompok yang diberi $\mathrm{CCl}_{4}$ selama 5 hari (kelompok B). Perlemakan dan peradangan hati yang terlihat pada kelompok tikus wistar yang diberi $\mathrm{CCl}_{4}$ (Gambar 2) terjadi karena karbon tetraklorida $\left(\mathrm{CCl}_{4}\right)$ yang diaktifkan oleh enzim sitokrom P-450 menjadi radikal trikloromentil peroks $\left(\mathrm{CCl}_{3}\right)$. Radikal bebas yang dihasilkan dapat menyebabkan autooksidasi pada asam lemak yang terdapat dalam membran sel, sehingga $\mathrm{CCl}_{4}$ dapat menyebabkan nekrosis dan steatosis di dalam sentrolobuler hati yang mengandung isoenzim sitokrom P-450 dengan konsentrasi tertinggi. ${ }^{5}$

Kelompok tikus yang diberikan ekstrak daun kelor selama 5 hari setelah pemberian $\mathrm{CCl}_{4}$ dihentikan (kelompok C) menunjukan regenerasi sel yang lebih banyak dan sel hepatosit sudah mulai normal (Gambar 3). Hal ini mungkin berhubungan dengan khasiat daun kelor sebagai hepatoterapeutik. ${ }^{1}$ Senyawa kimia quercetin dan silymarin golongan flavonoid yang terkandung dalam daun kelor berfungsi sebagai antioksidan. Quercetin memiliki aktivitas antioksidan yang memungkinkan flavonoid untuk menangkap atau menetralkan radikal bebas terkait dengan gugus $\mathrm{OH}$ fenolik sehinggadapat memperbaiki keadaan jaringan yang rusak dan proses inflamasi dapat terhambat. ${ }^{6}$ Silymarin memiliki efek hepatoterapeutik karena dapat meningkatkan kecepatan sintesis protein yang merangsang sel untuk beregenerasi lebih cepat, yaitu dengan mengganti sel-sel yang lama atau rusak selsel dengan baru. ${ }^{1}$

Berbeda dengan organ padat lainnya, hati memiliki kapasitas regenerasi yang besar. $^{7,8}$ Regenerasi ini berlangsung cepat dan membutuhkan waktu 5 sampai 7 hari pada tikus. Selama regenerasi hati, hepatosit diperkirakan mengalami replikasi sebanyak satu atau dua kali. Setelah tercapai ukuran dan volume hati sebelumnya, hepatosit kembali pada keadaan semula. ${ }^{9}$ Respon perbaikan hati terlihat pada hasil penelitian ini.Regenerasi sel hati ditemukan pada tikus kelompok IV, yaitu tikus yang diberikan $\mathrm{CCl} 4$ selama 5 hari dilanjutkan dengan pemberian pellet biasa selama 5 hari dan diterminasi pada hari ke-11 (Gambar 4).

Dengan demikian dapat dikatakan bahwa regenerasi sel hati terjadi lebih baik pada kelompok tikus yang diberi ekstrak daun kelor (kelompok C) dibandingkan dengan yang tidak diberikan ekstrak daun kelor setelah terjadi cedera sel yang diinduksi $\mathrm{CCl}_{4}$ (kelompok D). Jadi, kelompok tikus yang tidak diberikan ekstrak daun kelor membutuhkan waktu yang lebih lama untuk mengalami regenerasi sel hati. Hasil penelitian ini membuktikan bahwa penggunaan ekstrak daun kelor (moringa oleifera) dapat membantu mempercepat regenerasi sel hati akibat cedera (perlemakan) oleh $\mathrm{CCl}_{4}$.

Penelitian yang dilakukan ini sesuai dan menunjang penelitian-penelitian sebelumnya mengenai efektivitas daun kelor sebagai tanaman yang digunakan untuk mengobati penyakit hati dan penyakit yang disebabkan oleh zat toksik. Dwi et al. ${ }^{6}$ menggunakan serbuk daun kelor untuk menurunkan derajat perlemakan hati dan 
ekspresi interleukin-6 hati tikus dengan kurang energi protein. Penelitian lain oleh Suryaningrum ${ }^{10}$ menggunakan ekstrak daun kelor sebagai efek hepatoprotektif terhadap kerusakan hepar akibat obat isoniazid pada tikus wistar, sedangkan penelitian yang dilakukan oleh Toripah et al. ${ }^{11}$ menguji aktivitas antioksidan dan kandungan total fenolik ekstrak daun kelor.

Hasil penelitian ini dapat menambah informasi dan pengetahuan mengenai efek daun kelor bagi kesehatan organ hati dan menjadi acuan bagi penelitian-penelitian selanjutnya. Pengukuran kuantitatif per lapangan pandang terhadap jumlah sel regenerasi dan perlemakan hati dipandang perlu dilakukan pada penelitian-penelitian selanjutnya untuk mendapatkan hasil penelitian yang lebih akurat.

\section{SIMPULAN}

Hati tikus wistar yang diberi ekstrak daun kelor setelah induksi $\mathrm{CCl}_{4}$ memperlihatkan regenerasi sel pada hampir seluruh lobuli hati, lebih baik dari pada yang tidak diberi ekstrak daun kelor sehingga dapat disimpulkan bahwa ekstrak daun kelor dapat mempercepat regenerasi sel hati yang mengalami cedera akibat $\mathrm{CCl}_{4}$.

\section{SARAN}

1. Perlu dilakukan penelitian lebih lanjut dengan menggunakan dosis ekstrak daun kelor yang bervariasi untuk mendapatkan hasil yang optimal.

2. Perlu dilakukan penelitian lebih lanjut dengan jumlah sampel yang lebih banyak.

\section{DAFTAR PUSTAKA}

1. Krisnadi AD. Kelor super nutrisi. Kunduran Blora: Moringa Indonesia, 2015; p. 164.

2. Sjofjan O. Efek penggunaan tepung daun kelor (Moringa oleifera) dalam pakan terhadap penampilan produksi ayam pedaging. Puslitbang Peternakan,
2008; p. 649-56.

3. Lestari D. Efek protektif dari lecitin terhadap hepatotoksisitas akibat induksi karbon tetraklorida pada tikus putih (Rattus norvegicus) [Tesis]. Surabaya: Universitas Airlangga; 2008.

4. Kardena IM, Winaya Oka IB. Kadar perasan kunyit yang efektif memperbaiki kerusakan hati mencit yang dipicu karbon tetraklorida. Jurnal Veteriner. 2011;12(1):34-39.

5. Adikusuma W, Bachri MS. Efek hepatoprotektif serbuk akar pasak bumi (Eurycoma longifolia Jack) dilihat dari aktivitas spgt-sgot tikus jantan yang diinduksi $\mathrm{CCl}$. Pharmagiana. 2014;4:165-170.

6. Ikalinus R, Widyastuti SK, Setiasih NE. Skrining fitokimia ekstrak etanol kulit batang kelor (moringa oleifera). Indonesia Mediacus Veterinus. 2015;4(1);71-79.

7. AJunqueira CL, Carneiro J. Histologi Dasar teks dan atlas (10th ed). Jakarta: EGC, 2007; p. 501.

8. Setiati S, Alwi I, Sudoyo AW, Simadibrata M, Setiyohadi B, Syam AF. Fisiologi dan biokimia hati. In: Amirudin R, penyunting. Buku Ajar Ilmu Penyakit Dalam jilid II (6th ed). Jakarta: Pusat Penerbit Ilmu Penyakit Dalam, 2012; p. 1439.

9. Guyton AC, Hall JE. Hati sebagai suatu organ. In: Rachman LY, penyunting. Buku Ajar Fisiologi Kedokteran (11th ed). Jakarta: EGC, 2007; p. 1179.

10.Suryaningrum LD. Efek hepatoprotektif daun kelor (Moringa oleifera lam) terhadap kerusakan hepar akibat obat isoniazid pada tikus wistar. Universitas Sebelas Maret [Tesis]. Surakarta: Universitas Sebelas Maret; 2012.

11.Toripah SS, Abidjulu J, Wehantouw F. Aktivitas antioksidan dan kandungan total fenolik ekstrak daun kelor (Moringa oleifera). Jurnal Ilmiah Farmasi. 2014;4(3);34-37. 